\title{
Self-incompatibility in the Chilean Endemic Genus Leucocoryne Lindley
}

\author{
L. Mansur, M. Gonzalez, I. Rojas, P. Salas \\ Facultad de Agronomía, Pontificia Universidad Católica de Valparaíso, Casilla 4-D, Quillota, Chile
}

ADDITIONAL INDEX WORDS. selfing, inbreeding, reproduction, Huilli

\begin{abstract}
The Chilean genus Leucocoryne has exceptional qualities as an ornamental plant that is being developed through breeding. Little is known about the origin of its genetic variation for flower phenotype. Our hypothesis is that, despite having a perfect flower, Leucocoryne has an outbreeding behavior due to self-incompatibility. Greenhouse studies were conducted to study self-incompatibility. In 2000, one species L. purpurea Gay. and two distinct populations Leucocoryne sp. Pichicuy and Leucocoryne sp. Chigualoco were used, whereas in 2001, L. coquimbensis F. Phil. and Leucocoryne sp. Alcones and Leucocoryne sp. Talinay were added. Field studies were carried out in 2001 at La Campana (lat. $29^{\circ} \mathrm{S}$, Valparaíso Region, Chile) and Bosque de Fray Jorge (lat. $33^{\circ} \mathrm{S}$, Coquimbo Region, Chile) National Parks with $L$. ixioides Lindley and $L$. purpurea, respectively. The index of self-genetic incompatibility (ISI) was measured as the average number of seeds per fruit produced by self-pollination divided by the average number of seeds per fruit produced from cross-pollination. The average ISI values for 2000 and 2001 were 0.08 and 0.06 , respectively, meaning that Leucocoryne is largely self-incompatible. In the field seed set was compared between flowers that were isolated from insects and those that were not. None of the isolated flowers produced seeds, instead nonisolated flowers produced an average of 29 seeds per fruit at La Campana and 56 at Bosque de Fray Jorge. Leucocoryne's self-incompatibility and outcrossing behavior plus its capacity to fix any genotype via asexual reproduction, most likely contribute to its large variation for flower color, shape, size, design, and aroma. Due to Leucocoryne's reproductive behavior it would be difficult to breed for homozygous inbreds and pure hybrid cultivars
\end{abstract}

The genus Leucocoryne, commonly called Huilli, is endemic to Chile, and has exceptional qualities as an ornamental plant both as a cut flower and in landscaping. Its potential is being developed by plant breeding in Chile (Mansur, 2004). The habitat of the genus extends from the Atacama desert in northern Chile, near the city of Iquique (lat. 20 ${ }^{\circ}$ S) (Pinto, 1997) to the southern region in the humid Lake District, X Region, Chile (lat. $39^{\circ} \mathrm{S}$ ) (Muñoz, 2000). Its center of diversity appears to be in Central Chile. About $75 \%$ of the described species are found in Chile's IV and V Regions (Mansur, 2004; Zoellner, 1972), in an area bound by the cities of Valparaíso (lat. $33^{\circ} \mathrm{S}$ ) in the south to just north of the city of La Serena (lat. $29^{\circ} \mathrm{S}$ ) and from sea level to $2800 \mathrm{~m}$ above seal level.

For a geneticist, the most attractive characteristic of the genus Leucocoryne is its great variation in the shapes, designs, colors, and scents of its flowers (Mansur, 2004; Zoellner, 1972). Except for the pioneering work of Zoellner (1972) little is known about the origin of this diversity. He revised the genus using conventional morphology-based taxonomy and described 14 species. Crosa (1988) and Araneda et al. (2004) carried out cytogenetic studies and found that there is also variation for chromosome numbers with diploid $(2 n=10)$ and tetraploid species $(2 n=18)$. Further, there is karyotypic evidence (Araneda et al., 2004; Salas and Mansur, 2004) and morphological evidence (Moreno and Arancio, 2001) that there is gene flow between species from different ploidy levels. These studies concluded that intermediate individuals originated from natural hybridization between the diploid $2 \mathrm{n}=$ 10 L. purpurea and the tetraploid $2 \mathrm{n}=18 \mathrm{~L}$. coquimbensis. The morphology of the genus Leucocoryne corresponds to a perfect

Received for publication 27 Apr. 2004. Accepted for publication 21 May 2004. We thank Drs. R. Craig and C. Quiros for their valuable suggestions to improve the manuscript. The statistical assistance of Dr A. Carriquiry is also appreciated. This research was supported with funds from Fondo-SAG of the Servicio Agrícola y Ganadero, Chile flower of a self-pollinating plant. Its stigmas and stamens are enclosed in a staminal tube that would seem to facilitate seed production with its own pollen, instead of out-crossing (Mansur, 2004). Arroyo and Uslar (1993) found preliminary evidence for self-incompatibility in L. ixiodes. In this study we seek to show that the genus Leucocoryne is largely self-incompatible.

\section{Materials and Methods}

Plants. The germplasm used in this research is listed in Table 1. When the population has been taxonomically classified, its species name is indicated; those not yet taxonomically classified are denoted as populations and they are listed as Leucocoryne sp. followed by the name of the locations where they were collected. Photographs of these plants can be found in a published manual (Mansur, 2004).

GREENHOUSE STUDIES. In 2000, one species (L. purpurea) and two populations (Leucocoryne sp. Pichicuy and Leucocoryne sp. Chigualoco) were studied. Eighty bulbs from each group were planted in 80 pots and placed under two insect isolation structures with 40 pots each. In 2001, 80 bulbs from each of the species or population were also used and L. coquimbensis and Leucocoryne sp. Alcones and Leucocoryne sp. Talinay were added to the experiment. In this case, 40 pots from each species or population were left to naturally pollinate and were used as controls outside the isolation structure. The structures consisted of a wooden frame $(1.0 \times 2.6 \times 0.8 \mathrm{~m})$ covered with a 50-mesh net usually used to keep aphids out. All of these studies were conducted at the La Palma Experimental Station of the Facultad de Agronomía of the Pontificia Universidad Católica de Valparaíso, Quillota, Chile.

The level of genetic self-incompatibility was measured using the method described by Saavedra et al. (1996). Three flowers of the pseudo-umbel of the isolated plants that produced at least three flowers (Table 2) were subjected to three treatments. One random flower was emasculated at bud stage when the petals start 
Table 1. Collection date and place of origin of the Chilean endemic Leucocoryne species used for testing self-incompatibility.

\begin{tabular}{lcccll}
\hline Species & $\begin{array}{c}\text { Date of } \\
\text { Collection }\end{array}$ & Region & Province & \multicolumn{1}{c}{ City } & Locality \\
\hline L. purpurea & $1998-99$ & IV & Limarí & Ovalle-Coquimbo & Talinay-Guanaqueros \\
Leucocoryne sp. Pichicuy & 1999 & V & Petorca & La Ligua & Pichicuy \\
Leucocoryne sp. Chigualoco & 1999 & IV & Choapa & Los Vilos & Chigualoco \\
Leucocoryne sp. Alcones & 1997 & IV & Limarí & Ovalle & Alcones \\
L. coquimbensis & 1996 & IV & Elqui & Coquimbo & Las Tacas \\
Leucocoryne sp. Talinay & 1998 & IV & Limarí & Ovalle & Talinay \\
\hline
\end{tabular}

Table 2. Average number of seeds per fruit and index of genetic index self-incompatibility (ISI) for six genotypes of Leucocoryne

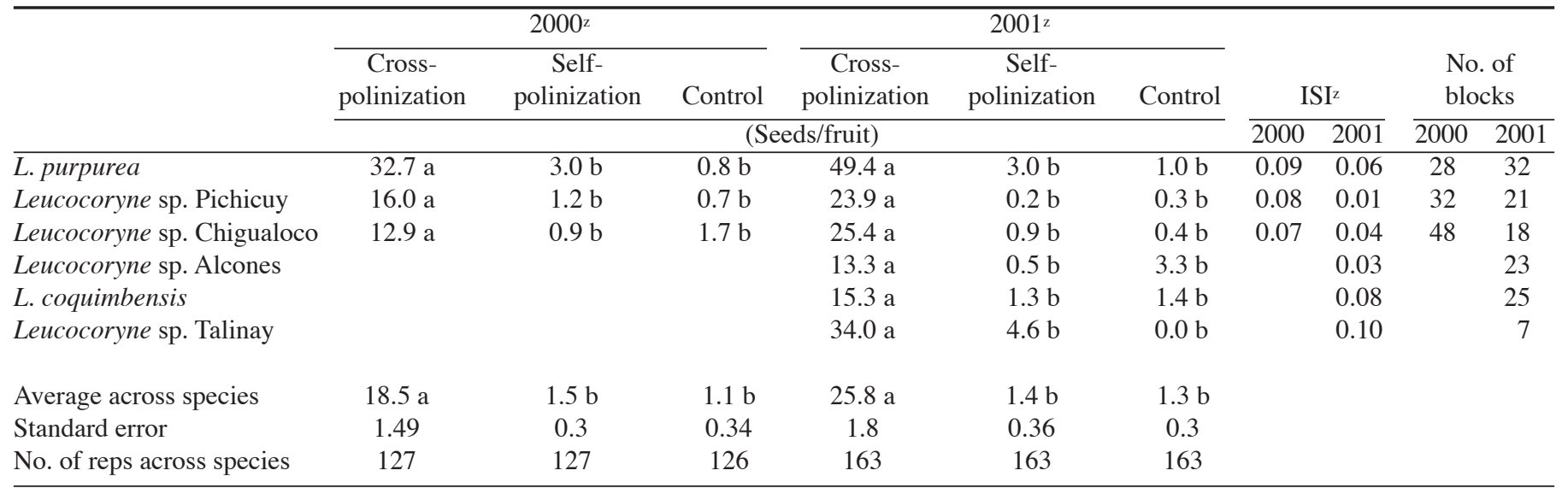

*Means followed by the same letter within a row and a year are not significantly different at the $P \leq 0.05$ using Friedman's multiple comparison ${ }^{2} \leq 0.2$ self-incompatible, $\geq 0.5$ totallly self-compatible

to gain pigmentation and then manually cross-pollinated with pollen from another plant of the same species or population. A second flower from the same stem was also emasculated at the same stage and manually self-pollinated with mature pollen from the same flower or from another flower from the same plant. A third flower from the same stem was not manipulated at all and was allowed to self-pollinate and left as a control. Crosses were made with mature pollen and receptive pistils. From experience it is known that mature pollen is released by a dehiscent anther and a pistil is receptive as soon as the petals in the buds start gaining pigmentation. The response variable was the number of seeds per fruit.

FiELD STUdies. In 2001, two field trials were conducted in both La Campana (Valparaíso Region, lat. $29^{\circ} \mathrm{S}$ ) and Bosque de Fray Jorge (Coquimbo Region, lat. $33^{\circ} \mathrm{S}$ ) National Parks with $L$. ixioides and $L$. purpurea, respectively. A group of randomized plants was located in each park before flowering and used for the experiment. At La Campana, 11 plants were used and data were taken from one stem per plant. One flower per plant was covered preventing insect pollination. The remaining flowers were not manipulated. Instead, at Bosque de Fray Jorge four plants were covered with a structure similar to the one described before, and nine plants within a $30-\mathrm{m}$ radius were left uncovered as controls. In this case, flowers from all the stems produced by the plants were evaluated. The fruits were collected 16 and 18 Nov. 2001 in La Campana and in Bosque de Fray Jorge, respectively.

STATISTICALANALYSES. The greenhouse experiments were analyzed considering each species or population of plants each year as independent experiments. Later, the data set from all species and populations was combined and a single analysis done for $\mathrm{Leu}$ - cocoryne as a genus each year. The experiments were conducted in a complete random block design where an inflorescence with its pseudo umbel having at least three flowers (i.e., treatments) was considered a block. Due to the lack of normal distribution of the data; we used Friedman's two-way rank analysis, which is a nonparametric method of statistics analysis. To test the null hypothesis that the treatments within a block are identical, a test of multiple comparison of free distribution based on the sum of ranks was used (Friedman, 1937; Hollander et al., 1973). For this purpose, plants without flowers and those producing no seeds in all three treatments were discarded. The number of plants used for the analyses is listed in Table 2. The index of self-genetic incompatibility (ISI) (Arroyo and Uslar, 1993), was calculated as follows: ISI = average number of seeds per fruit from self-pollination treatments / average number of seed per fruit from crosspollination treatments. The upper ISI value for self-incompatible species is 0.2 and the lower ISI value for complete self-compatible species is 0.5 (Arroyo and Uslar, 1993)

For the field experiments, the number of seeds per fruit of covered and uncovered plants was counted and to make meaningful comparisons, the standard error for the averages were computed (Table 2).

\section{Results and Discussion}

The differences in seed production indicated that Leucocoryne clearly tends to self-incompatibility and out crossing given that no differences were found, in all the species studied, between the manually self-pollinated and the unpollinated control treatments, however, a highly significant number of seeds was produced by 
cross-pollination in all cases (Table 2). All species and distinct populations behaved similarly and showed no significant differences within each year. The average seed production per fruit for manually self-pollinated and unpollinated control for all the Leucocoryne studied was close to 1.0 in both the 2000 and 2001. Meanwhile, the average seed production per fruit in the cross-pollination treatment was 18 in 2000 and 25 in 2001. This leads to ISI of 0.08 for the 2000 and 0.06 for the 2001 experiments, respectively. These results are similar to those obtained by Arroyo and Uslar (1993) who calculated an ISI of 0.056 for L. ixioides, with 0.2 being the upper limit for self-incompatible species (Saavedra et al., 1996).

The experiments conducted in the field confirmed the above results. At La Campana out of 11 isolated flowers of L. ixioides, none produced seeds, whereas those exposed to insects produced an average of 29 seeds per fruit. Similarly, at Bosque de Fray Jorge four isolated plants of $L$. purpurea, having 24 flowers altogether, did not produce seeds. However, the nine surrounding plants, which were not isolated produced an average of 56 seeds per fruit. According to our observations Leucocoryne in the wild can produce up to 80 seeds per fruit and up to 500 seeds per plant

It is reasonable to expect that Leucocoryne's self-incompatibility and outcrossing behavior plus its capacity to fix any genotype via asexual reproduction, contribute to its large variation for flower color, shape, size, design and aroma (Aliaga, 2003; Mansur, 2004).

Furthermore, self-incompatibility has important consequences for plant breeding in that it makes it difficult to produce homozygous lines and breed for pure hybrids. In order to do this a breeder would need to overcome its self-incompatibility and inbreeding depression that is likely to occur due to deleterious recessives that may appear during the inbreeding process. Alternatively, any interesting genotype could be maintained or multiplied via asexual reproduction or propagation in vitro.

\section{Literature Cited}

Aliaga C. 2003. Estudio de descriptores morfológicos para una caracterización de seis poblaciones de Leucocoryne sp. en clases de peso. Thesis. Pontificia Universidad Católica de Valparaíso, Facultad de Agronomía, Quillota, Chile.

Araneda L., P. Salas, and L. Mansur. 2004. Chromosome numbers in the Chilean endemic genus Leucocoryne (Huilli). J. Amer. Soc. Hort. Sci. 129:77-80.

Arroyo, M and P. Uslar. 1993. Breeding systems in a temperate mediterranean-type climate montane sclerophyllous forest in central Chile. Bot. J. Linnean Soc. 111:83-102.

Crosa, O. 1988. Los cromosomas de nueve especies del género chileno Leucocoryne Lindley, (Alliae - Alliacea). Boletín Facultad de Agronomía. Universidad de la República. Uruguay. 17:1-12.

Friedman 1937. The use of ranks to avoid the assumption of normality implicit in the analysis of variance. J. Amer. Statistical Assn. 32:675-701.

Hollander, M., D. Woife, and J. Wile. 1973. Nonparametric statistical methods. Wiley, New York.

Mansur, L. 2004. Life cycle, self-incompatibility, and genetic plasticity in the design and color of Leucocoryne flowers, p. 9-15. In: Leucocoryne: A native Chilean genus and its use as a garden plant. Reimco Ltda., Viña del mar, Chile.

Moreno R. and G. Arancio. 2001. Posibles híbridos naturales entre dos especies del género Leucocoryne. Gayana 58(1):86-87.

Muñoz, M. 2000. Consideraciones sobre los géneros endémicos de monocotiledóneas de Chile. Boletín Museo Nacional Historia Natural 343:16-27.

Pinto, R.1997. Oasis de Niebla, El Niño 1997. Iquique, Chile.

Saavedra, F., M. Arroyo, and A. Hoffmann. 1996. The breeding system of Hippeastrum advenum (Ker-Gawl.) Herb. (Amaryllidaceae), an endemic geophyte of the mediterranean-type climate region in central Chile. Botanische Jahrbücher für Systematik 118(1):1-8.

Salas P. and L. Mansur. 2004. Gene flow between parents with different ploidy level in a natural population of Leucocoryne. J. Amer. Soc. Hort. Sci. In Press

Zoellner, O. 1972. El género Leucocoryne. Anales Museo Historia Natural Valparaíso 5: 9-83 